\title{
Improving Productivity of Wheat Through Mulching and Foliar Nutrition in Late Sown Wheat
}

\author{
V. C. Dhyani", Rajeew Kumar, D. S. Pandey, V. P. Singh, I. P. Singh, Yogesh Sharma and Sumit Chaturvedi
}

Dept. of Agronomy, G. B. Pant University of Agriculture \& Technology, Pantnagar, Uttarakhand (263 145), India

\section{Article History}

Manuscript No. AR1564

Received in $16^{\text {th }}$ March, 2016

Received in revised form $28^{\text {th }}$ August, 2016

Accepted in final form $20^{\text {th }}$ September, 2016

\section{Correspondence to}

*E-mail: dhyanivipin@gmail.com

\section{Keywords}

Late sown wheat, mulching, foliar nutrition, chlorophyll florescence

\begin{abstract}
The experiments were conducted during winter season of 2011-12 and 2012-13 to evaluate heat stress response of wheat to paddy straw mulch and foliar nutrition of calcium and potassium in irrigated situation of mollisols of GBPUAT, Pantnagar, Uttarakhand, India. The treatments comprised of paddy straw mulch at $6 \mathrm{tha}^{-1}$ (just after sowing) and no mulch as the first factor and 6 foliar nutrition of Calcium Chloride $(0.1 \%)$ and Potassium Chloride $(0.2 \%)$ at booting and post-anthesis stage (one week after anthesis) along with two treatments having water spray with same spray volume i.e. $3001 \mathrm{ha}^{-1}$ applied at booting and post-anthesis stages and no-spray as the second factor. All yield attributing characters were on higher side in mulch treated plots compared to non-mulch however the values were non-significant. Grain yield was significantly higher in mulched plots than non-mulch. Foliar spray of $\mathrm{KCl}$ at $0.2 \%$ at post-anthesis stage increased the productivity of wheat significantly compared to control and other foliar treatments. All other foliar treatments were at par with control with respect to grain yield of wheat. Climatic condition particularly the rainfall distribution and temperature regime had effect on crop productivity. The betterment of yield due to these treatments was due to better efficiency of PSII accentuated by higher value of Fv Fm-1. The effect of treatments did not influence phenology of crop.
\end{abstract}

\section{Introduction}

Wheat (Triticum aestivum L.) is one of the most important crops of World, and improvement in its productivity has played a key role in making several countries self-sufficient in food production. However, in the past decade there has been marginal increase in the productivity wheat, particularly under environments relatively favorable for growth and development of wheat (Joshi et al., 2007) mainly due to terminal heat stress. Terminal heat stress largely refers to rise in temperatures at the time of grain growth. In wheat, high temperatures $\left(>30^{\circ} \mathrm{C}\right)$ after anthesis can decrease the rate of grain-filling (Wardlaw and Moncur, 1995), while high temperatures imposed before anthesis can also decrease yield (Wardlaw et al., 1989a). Yield loss due to every degree rise in temperature is more severe than water availability (Bennett et al., 2012). Main reason of terminal heat stress is late planting caused by late picking of cotton and late harvesting of sugarcane, rice and maize crop in different agro climatic zones (Irfaq et al., 2005). Numerous other factors as lack and untimely availability of irrigation water, farm machinery (tractors, seed drills etc.) fertilizers and any rain after harvesting of the preceding crop (sugarcane, rice, cotton etc.) may further delay wheat sowing (Byerlee, 1986). The adverse effects of drought and heat stress can be mitigated by soil management practices, crop establishment, and foliar application of growth regulators by maintaining an appropriate level of water in the leaves due to osmotic adjustment and stomatal performance (Lipiec et al., 2013). Foliar application of nutrients and other compounds may help to alleviate the effect of heat stress. Foliar application of potassium, calcium compounds, arginine and micronutrient zinc. Calcium $\left(\mathrm{Ca}^{2+}\right)$ helps to protect the photosynthetic system of wheat leaves from oxidative damage induced by the heat stress thereby caused tolerance to heat stress (Zhao and Tan, 2005). Application of $\mathrm{CaCl}_{2}$ can reduce the impact of heat stress in wheat to considerable level (Hairat and Khurana, 2015). Application of potassium can help as potassium has the major role in osmoregulation, photosynthesis, transpiration, stomatal opening and closing and synthesis of protein etc. (Cakmak, 2005; Milford and Johnston, 2007). Application $\mathrm{KCl}$ has reported to increase the yield of wheat under heat 
stress (Kajla et al., 2015). The plant water status is the most important variable under changing ambient temperatures (Mazorra et al., 2002). In general, plants tend to maintain stable tissue water status regardless of temperature when moisture is ample; however, high temperatures severely impair this tendency when water is limiting (Machado and Paulsen, 2001). Water deficit around anthesis may lead to a loss in yield by reducing spike and spikelet number and the fertility of surviving spikelet and from anthesis to maturity, especially if accompanied by high temperature hasten leaf senescence, reduces the duration and rate of grain filling and hence reduce mean kernel weight (Royo, 2000). Further hand crop lodging is a chronic constraint, commonly limiting irrigated spring wheat yields. To avoid lodging, many farmers in south Asia forego the last irrigation (Hobbs et al., 1997), which may be crucial for grain filling and can ultimately limit grain yield. Application of paddy straw mulch in the field can enhance the water availability for longer period of time and can also alleviate adverse effect of terminal heat stress. It also gives an opportunity to withhold last irrigation. Combination of irrigation with mulch technology is advocated for better uptake of water by the spring wheat (Li et al., 2004) and to reduce the number of irrigation (Mandal and Ghosh, 1984). These results have strongly established that the conserved moisture through mulching has been very effective to plants during stress. Mulching can affect the temperature and moisture content of the soil (Acharya et al., 2005) and directly influence the grain yield of crops (Li et al., 2001a, b). Straw mulching systems can conserve soil water and reduce temperature because they reduce soil disturbance and increase residue accumulation at the soil surface (Zhang et al., 2009).

Moisture conservation practices and foliar application of nutrients are well documented in heat stress mitigation. However, timing of foliar application needs to be worked out for effective response under late sown condition. Therefore, this study aimed at investigating the effect of mulching and foliar nutrition of Calcium and Potassium Chloride on heat stress in late sown wheat under adequate soil nutrition.

\section{Materials and Methods}

Wheat variety UP 2526 was sown in field experiment on $22^{\text {nd }}$ December, 2011 and $12^{\text {th }}$ December, 2012, respectively at the N. E. Borlaug Crop Research Centre, Pantnagar, Uttarakhand, India in order to expose crop to terminal heat stress. Optimum sowing time for wheat in North India is around 10-20 November. The experiment was set up as a two factor randomized block design with 3 replicates. The treatments comprised of paddy straw mulch at $6 \mathrm{t} \mathrm{ha}^{-1}$ (just after sowing) and no mulch as the first factor and foliar nutrition of Calcium Chloride (0.1\%) and Potassium Chloride
$(0.2 \%)$ at booting and post-antheiss stage (one week after anthesis) along with two treatments having water spray (same spray volume of $3001 \mathrm{ha}^{-1}$ as in other treatments) at booting and post-anthesis stages and no-spray as the second factor. Combination of first and second factor was randomized in the experiment. The $1 / 3^{\text {rd }}$ of recommended nitrogen $(120 \mathrm{~kg})$ along with full recommended phosphorous and potassium (60 and $40 \mathrm{~kg}$ respectively) applied at the time of sowing. Other package of practices was adopted as per recommendation including irrigation. Plots were frequently irrigated as and when required to avoid drought stress. In total four (on $15^{\text {th }}$ January, 2012, 10 $0^{\text {th }}$ February, 2012, $8^{\text {th }}$ March 2012 and on $4^{\text {th }}$

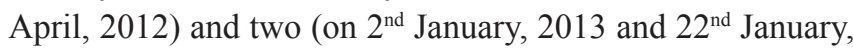
2013) irrigation were applied to crop during first and second year respectively. Available nitrogen, phosphorous potassium and calcium in the soil were 213.2, 19.1, and 192.4 and 300.6 $\mathrm{kg} \mathrm{ha}^{-1}$, respectively in the experimental soil at the start of the experiment.

\subsection{Weather data and analysis}

Weather analysis showed that maximum temperature rose to $30{ }^{\circ} \mathrm{C}$ on $89^{\text {th }}$ day during $2011-12$ while during $2012-13$ on $100^{\text {th }}$ day. Rainfall received during the crop season was 37.0 mm during 2011-12 while during 2012-13, it was $188 \mathrm{~mm}$ and it was well distributed. The arrival of anthesis coincided with the rise of maximum temperature beyond $30{ }^{\circ} \mathrm{C}$ during both the years along with increased evaporation. Night temperature remained higher than $15^{\circ} \mathrm{C}$ during much of postanthesis stage in the first year while it was cooler in the second year. Over all weather condition in terms of temperature and rainfall were more conducive during second year than first year for wheat production under late sown condition.

The chlorophyll fluorescence ratio $\left(\mathrm{Fv} \mathrm{Fm}^{-1}\right)$ was measured on flag leaves using an OS-30p hand held chlorophyll flurometer (Opti-Sciences, Inc. 8 Winn Avenue Hudson NH 03051 USA). The soil moisture at 100 and 110 days after sowing (DAS) was determined by a Time domain reflectometer (Field Scout TDR 300 Soil Moisture Meter from Spectrum Technologies, 3600 Thayer Court, Aurora, Illinois, USA) from the top 10 cm of soil.

All the experiments were done in a completely randomized block design. For each treatment, three replications were maintained. The data were subjected to one-way ANOVA followed by separation of means at $p=0.05$ in the standard programme developed by Department of Mathematics, Statistics and Computer Science of our University.

\section{Results and Discussion}

\subsection{Soil moisture}

Volumetric soil moisture content (\%) was taken at 100 days 
and 110 days after sowing during both the years through time domain reflectometer (Figure 1). It was observed that soil moisture content was high under paddy straw mulch (11.7)

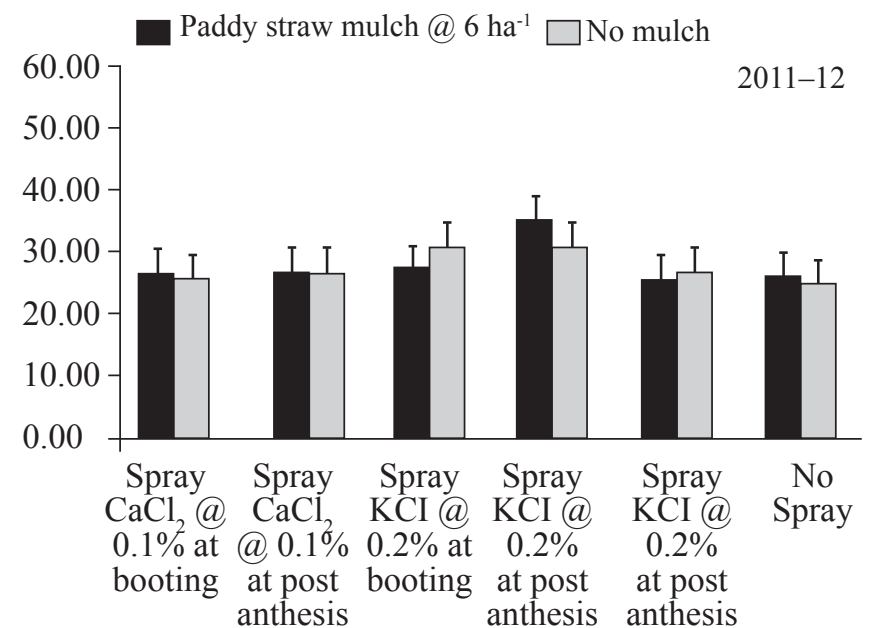

compared to non-mulch (10.7). During first year, at both the stages due to less rainfall at 100 and 110 days stage, soil moisture content was less compared to second year. During

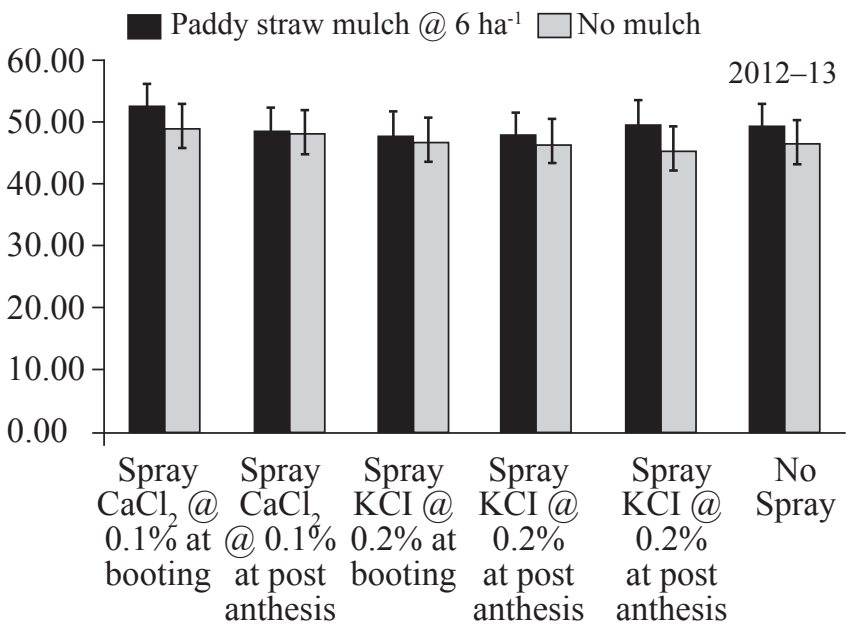

Figure 1: Interaction effect of mulching and foliar nutrition on wheat grain yield ( $\left.\mathrm{q} \mathrm{ha}^{-1}\right)$. Bars are $\mathrm{CD}(p=0.05)$

second year good amount of rainfall was received resulted in better soil moisture regime.

\subsection{Physiological and phenological parameters}

Table 1 shows combined analysis of various physiological and phenological parameters influenced by different treatments. Maximal efficiency of photosystem II represented by ratio of variable florescence to the maximal florescence $\left(\mathrm{Fv} \mathrm{Fm}{ }^{-1}\right)$ was observed to be significantly higher in paddy straw mulch at 110 days (0.54) compared to non-mulch (0.53) however

Table 1: Physiological, phenological parameters, yield attributes, grain and biological yield as influenced by treatments Pooled data of two years (2011-12 and 2012-13)

\begin{tabular}{|c|c|c|c|c|c|c|c|c|c|c|}
\hline Treatments & $\begin{array}{c}\mathrm{Fv} \mathrm{Fm}^{-1} \\
100 \\
\text { DAS }\end{array}$ & $\begin{array}{c}\mathrm{Fv} \mathrm{Fm}^{-1} \\
110 \\
\text { DAS }\end{array}$ & DH & DA & $\mathrm{DM}$ & $\begin{array}{c}\text { Ear- } \\
\text { head } \\
\mathrm{m}^{-2}\end{array}$ & $\begin{array}{l}\text { Grains } \\
\text { spike }^{-1}\end{array}$ & $\begin{array}{c}\text { Test } \\
\text { weight } \\
\text { (g) }\end{array}$ & $\begin{array}{l}\text { Grain } \\
\text { yield } \\
\left(\mathrm{q} \mathrm{ha}^{-1}\right)\end{array}$ & $\begin{array}{c}\text { Biological } \\
\text { yield } \\
\left(\mathrm{q} \text { ha }^{-1}\right)\end{array}$ \\
\hline Paddy straw mulch $\left(6 \mathrm{ha}^{-1}\right)$ & 0.68 & 0.54 & 75.2 & 81.1 & 120.0 & 345 & 38.6 & 37.2 & 36.21 & 57.79 \\
\hline No mulch & 0.68 & 0.53 & 75.3 & 81.0 & 119.6 & 337 & 38.4 & 37.3 & 35.06 & 59.09 \\
\hline $\operatorname{SEm} \pm$ & 0.002 & 0.002 & 0.15 & 0.14 & 0.15 & 6.6 & 0.5 & 0.3 & 0.33 & 0.56 \\
\hline $\mathrm{CD}(p=0.05)$ & NS & 0.006 & NS & NS & NS & NS & NS & NS & 0.95 & NS \\
\hline $\begin{array}{l}\text { Spray } \mathrm{CaCl}_{2} @ 0.1 \% \text { at } \\
\text { booting }\end{array}$ & 0.69 & 0.56 & 75.9 & 81.5 & 119.5 & 360 & 38.2 & 37.3 & 36.03 & 59.21 \\
\hline $\begin{array}{l}\text { Spray } \mathrm{CaCl}_{2} @ 0.1 \% \text { at } \\
\text { post-anthesis }\end{array}$ & 0.68 & 0.56 & 75.1 & 81.2 & 119.9 & 323 & 38.8 & 37.8 & 35.21 & 57.92 \\
\hline $\begin{array}{l}\text { Spray } \mathrm{KCl} @ 0.2 \% \text { at } \\
\text { booting }\end{array}$ & 0.68 & 0.52 & 75.3 & 80.5 & 119.8 & 337 & 39.3 & 36.2 & 35.92 & 58.90 \\
\hline $\begin{array}{l}\text { Spray KCl@0.2\% at } \\
\text { post-anthesis }\end{array}$ & 0.68 & 0.57 & 75.3 & 80.8 & 120.2 & 359 & 37.8 & 38.1 & 37.73 & 61.40 \\
\hline $\begin{array}{l}\text { Spray water at booting and } \\
\text { post-anthesis }\end{array}$ & 0.67 & 0.51 & 75.3 & 81.0 & 119.8 & 331 & 39.0 & 37.3 & 34.55 & 56.80 \\
\hline No spray & 0.67 & 0.48 & 74.6 & 81.1 & 119.6 & 336 & 38.0 & 36.9 & 34.38 & 56.41 \\
\hline $\operatorname{SEm} \pm$ & 0.004 & 0.004 & 0.26 & 0.24 & 0.27 & 11.5 & 0.9 & .6 & 0.58 & 0.96 \\
\hline $\mathrm{CD}(p=0.05)$ & 0.01 & 0.01 & 0.76 & NS & NS & 32.9 & NS & 1.6 & 1.65 & 2.75 \\
\hline
\end{tabular}

Fv Fm ${ }^{-1}$ : Ratio of variable to maximum florescence; DH: Days to heading; DA: Days to anthesis; DM: Days to maturity 
at 100 days stage differences were non-significant. Foliar treatments too had significant effect on $\mathrm{Fv} \mathrm{Fm}^{-1}$ parameter. All the chemical treated plots were at par in terms of this parameter however remained statistically superior to water spray and no-spray at both stages (100 and 110 DAS). Highest and lowest value of $\mathrm{Fv} \mathrm{Fm}{ }^{-1}$ was observed in $\mathrm{KCl}$ $(0.2 \%$ at post-anthesis stage) treated plot $(0.57)$ and no-spray $(0.48)$ treatments respectively. Wheat cultivars selected for high $\mathrm{Fv} \mathrm{Fm}^{-1}$ under heat stress maintain high photosynthesis, total chlorophyll, stomatal conductance, transpiration and dry matter (Sharma et al., 2014). This means that at 110 days stage photosynthetic apparatus remained better in paddy straw mulch treated plot than no mulch treatment. Also Since soil moisture content was also less during the grain filling stage thus; application of $\mathrm{KCl}$ might have helped the crop with standing that situation. The days to $75 \%$ heading $(\mathrm{DH})$, days to $75 \%$ anthesis (DA) and days to $75 \%$ maturity (DM) were non-significantly affected by the treatments i.e. due to mulch or foliar application of nutrients.

\subsection{Effect on yield attributes and yield}

Interaction between mulch treatments and foliar nutrition was non-significant. All yield attributing characters were on higher side in mulch treated plots compared to nonmulch however the values were non-significant. In wheat significantly higher number of grains spike ${ }^{-1}$ were recorded in rice straw mulch @ $4 \mathrm{t} \mathrm{ha}^{-1}$ compared to no mulch (Sarwar, 2013). Grain yield though was significantly superior under mulch treated plots (36.21 $\left.\mathrm{q} \mathrm{ha}^{-1}\right)$ than no mulch (35.06 $\mathrm{q} \mathrm{ha}^{-}$ $\left.{ }^{1}\right)$. Although there was non-significant difference between mulch and non-mulch with respect to different yield attributes still they were on higher side in the mulch treated plots and their combined effect produced significantly higher yield in mulched plots. Application of $\mathrm{KCl}$ at $0.2 \%$ concentration at post-anthesis stage resulted in significantly higher value of spikes $\mathrm{m}^{-2}$ (359) and grain yield (37.73 $\mathrm{q} \mathrm{ha}^{-1}$ ) compared to all other treatments. Better photosynthetic apparatus (higher value of Fv Fm ${ }^{-1}$ shown in Table 1) might have resulted in better crop performance and yield. Khan et al., 2006 reported that foliar application two sources of potash i.e. $\mathrm{KNO}_{3}$ and $\mathrm{KCl}$ are equally effective in increasing wheat yield and can be helpful in achieving maximum realizable yield. As indicated earlier that soil moisture was less at 100 and 110 days stage, crop might have got quickly greater supply of potassium through foliar spray at grain filling stage. At booting stage, since heat stress was not experienced by the crop, the effect of foliar applied potassium was not pronounced compared to post anthesis stage. Soil applied potassium does not become available to plant when needed, or plant cannot absorb through soils quickly and meet $\mathrm{K}$ requirements (Khan et al., 2006). Calcium Chloride (0.1\%) applied at booting stage also had significantly higher yield compared to no-spray probably because heat stress is perceived by perturbation to cellular equilibrium, which then activates signals possibly by hydrogen peroxide $\left(\mathrm{H}_{2} \mathrm{O}_{2}\right)$, abscisic acid (ABA), calcium $\left(\mathrm{Ca}^{2+}\right)$ and nitric oxide (NO). These signals then induce synthesis of specific protein kinases, which activate more downstream responses such as changes in gene expression. The response to these signalling cascades also results in changes in plant metabolism, activation and synthesis of antioxidants, synthesis of heat shock proteins, and accumulation of osmoprotectants and solutes, and reduces senescence under heat stress (Farooq, 2011). In present investigation however there was non-significant difference in phenology of crop due to different foliar treatments.

Interaction effect with regard to mulching and foliar nutrition was non-significant however during first year; foliar spray of $\mathrm{KCl}$ at post-anthesis stage was more effective in mulched plots compared to non-mulched plots in terms of producing grain yield. Paddy straw mulched conserved more water at post-anthesis stage and together with foliar application of $\mathrm{KCl}$ might have resulted higher grain yield compared to no mulch. The mulch layer on the field surface can weaken the intensity of turbulent exchange between the atmosphere and soil water, which cause soil moisture to be prevented from evaporating, and thus reduce ineffective water consumption (Dong and Qian, 2002). Since very light flood irrigation is possible at the grain filling stage, soil moisture content remains low due to high evaporation (Figure 2) and might have caused water scarcity at that stage. Further, an adequate $\mathrm{K}$ (through spraying here) status may facilitate osmotic adjustment, which maintains higher turgor pressure, relative

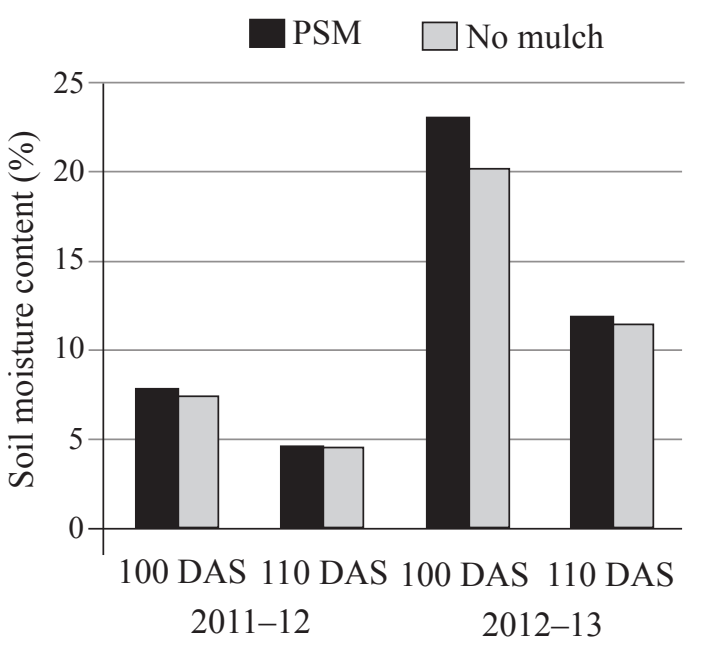

Figure 2: Soil moisture content (\%) of the experimental field at 100 and 110 days after sowing during two years 
water content and lower osmotic potential, thus improving the ability of plants to tolerate incipient moisture scarcity (Egilla, 2005)

\section{Conclusion}

Under late sown condition significantly higher grain yield of wheat can be obtained with paddy straw mulch $\left(6 \mathrm{t} \mathrm{ha}^{-1}\right)$ than non-mulch. Foliar application of $\mathrm{KCl}(0.2 \%)$ at post-anthesis stage helped to obtain higher grain yield with enhanced effect under paddy straw mulch.

\section{References}

Acharya, C.L., Hati, K.M., Bandyopadhyay, K.K., 2005. Mulches. In: Hillel, D., Rosenzweig, C., Pawlson, D.S., Scow, K.M., Sorger, M.J., Sparks, D.L., Hatfield, J. (Eds.), Encyclopedia of Soils in the Environment, Elsevier Publication, 521-532.

Bennett, D., Izanloo, A., Reynolds, M., Kuchel, H., Langridge, P., Schnurbusch, T., 2012. Genetic dissection of grain yield and physical grain quality in bread wheat (Triticum aestium L.) under water-limited environments. Theoretical and Applied Genetics 125, 255-271.

Byerlee, D., Hobbs, P., Khan, B.R., Majid, A., Akhtar, M. R., Hashmi, N.I., 1986. Increasing wheat productivity system: A view from the farmeris field. PARC News, 7, 21-23.

Cakmak, I., 2005. The role of potassium in alleviating detrimental effects of abiotic stresses in plants. Journal of Plant Nutrition and Soil Science 168, 521-530.

Dong, Z.Y., Qian B.F., 2002. Field investigation on effects of wheat-straw/corn-stalk mulch on ecological environment of upland crop farmland. Journal of Zhejiang University Science B 3(2), 209-215.

Egilla, J.N., Davies, F.T., Boutton, T.W., 2005. Drought stress influences leaf water content, photosynthesis and water-use efficiency of Hibiscus rosa-sinensis at three potassium concentrations. Photosynthetica 43, 135140 .

Farooq, M., Bramley, H., Palta, J.A., Siddique, K., 2011. Heat stress in wheat during reproductive and grain-filling phases. Critical Reviews in Plant Sciences 30, 491-507.

Hairat, S., Khurana, P., 2015. Improving photosynthetic responses during recovery from heat treatments with brassinosteroid and calcium chloride in Indian bread wheat cultivars. American Journal of Plant Sciences 6, 1827-1849.

Hobbs, P.R., Giri, G.S., Grace, P., 1997. Reduced and zero tillage options for the establishment of wheat after rice in south Asia. RCW Paper No. 2. Mexico, D. F., RiceWheat Consortium for the Indo-Gangetic Plains and CIMMYT.

Irfaq, M., Muhammad, T., Amin, M., Jabbar, A., 2005. Performance of yield and other agronomic characters of four wheat genotypes under heat stress. International Journal of Botany 1(2), 124-127.

Joshi, A.K., Mishra, B., Chatrath, R., Ortiz Ferrara, R., Singh. R.P., 2007. Wheat improvement in India: present status, emerging challenges, and future prospects, Euphytica doi:10.1007/s10681-007-9385-7.

Kajla, M., Yadav, V.K., Chhokar, R.S., Sharma, R.K., 2015. Management practices to mitigate the impact of high temperature on wheat. Journal of Wheat Research 7(1), $1-12$.

Khan, M.Z., Muhammad, S., Naeem, M., Ehsan, A., Khalid, M., 2006. Response of some wheat varieties to foliar application of $\mathrm{N}$ and $\mathrm{K}$ under rainfed condition. Pakistan Journal of Botany 38(4), 1027-1034.

Li, F.M., Yan, X., Wang, J., Li, S.Q., Wang, T.C., 2001a. The mechanism of yield decrease of spring wheat resulted from plastic film mulching. Agricultural Sciences in China 34, 330-333.

Li, X.Y., Gong, J.D., Gao, Q., Li, F., 2001b. Incorporation of ridge and furrow method of rainfall with mulching for crop production under semiarid conditions. Agricultural Water Management 50,173-183.

Lipiec, J., Doussan, C., Nosalewicz, A., Kondracka, K., 2013. Effect of drought and heat stresses on plant growth and yield: a review. International Agrophysics 27, 463-477.

Machado, S., Paulsen, G.M., 2001. Combined effects of drought and high temperature on water relations of wheat and sorghum. Plant and Soil 233, 179-187.

Mandal, B.K., Ghosh, T.K., 1984. Efficacy of mulches in the reduction of irrigation requirement of groundnut. Indian Journal of Agricultural Sciences 54, 446-449.

Mazorra, L.M., Nunez, M., Hechavarria, M., Coll, F., Sanchez Blanco, M.J., 2002. Influence of brassinosteroids on antioxidant enzymes activity in tomato under different temperature. Plant Biology 45, 593-596.

Milford, G.F.J., Johnston, A.E., 2007. Potassium and nitrogen interactions in crop production. In: Proceedings No. 615, International Fertiliser Society, York, UK, 1-21.

Royo, C., Abaza, M., Blanco, R., Garcya L.F., Moral, del, 2000. Triticale grain growth and morphometry as affected by drought stress, late sowing and simulated drought stress. Australian Journal of Plant Physiology 27, 1051-1059. 
Sarwar, M.A., Akbar, N., Javeed, H.M.R., Shehzad, M.A., Mehmood, A., Abbas, H.T., 2013. Response of zero tilled wheat crop to different mulching techniques in a semi-arid environment. International Journal of Advanced Research 1(9), 768-776.

Sharma, D.K., Fernandez, J.O., Rosenqvist, E., Ottosen, C.O., Andersen, S.B., 2014. Genotypic response of detached leaves vs. intact plants for chlorophyll fluorescence parameters under high temperature stress in wheat Journal of Plant Physiology 171, 576-586.

Stone, P.J., Savin, R., Wardlaw, I.F., Nicolas, M.E., 1995. The influence of recovery temperature on the effects of a brief heat shock on wheat. I. Grain growth. Australian Journal of Plant Physiology 22, 945-954.

Wardlaw, I.F., Dawson, I.A., Munibi, P., 1989a. The tolerance of wheat to high temperatures during reproductive growth: II. Grain development. Australian Journal of Agricultural Research 40, 15-24.

Wardlaw, I.F., Moncur, L., 1995. The response of wheat to high temperature following anthesis. I. The rate and duration of kernel filling. Australian Journal of Plant Physiology 22, 391-397.

Zhang, S.L., Lovdahl, L., Grip, H., Tong, Y.A., Yang, X. Y., Wang, Q.J., 2009. Effects of mulching and catch cropping on soil temperature, soil moisture and wheat yield on the Loess Plateau of China. Soil and Tillage Research 102, 78-86.

Zhao, H.J., Tan, J.F., 2005. Role of calcium ion in protection against heat and high irradiance stress-induced oxidative damage to photosynthesis of wheat leaves. Photosynthetica 43, 473-476. 